\title{
Adults' dental treatment in 2001-2013 in Finnish public dental service
}

\author{
J. Linden ${ }^{1 *}$, E. Widström ${ }^{2,3}$ and J. Sinkkonen ${ }^{4}$
}

\begin{abstract}
Background: All adults over 17 years of age have access to the Public Dental Service after the Finnish Dental Care Reform in 2001-2002. This study aimed to survey the treatment needs and treatment measures provided for adult patients and changes in these during the period 2001-2013.

Methods: Sing each person's unique identifier, demographic data on dental visits during the period 2001-2013 were collected from municipal databases in five PDS-units covering 320,000 inhabitants. The numbers of visitors, those in need of basic periodontal or caries treatment (CPI $>2$ and $D+d>0$ ) were calculated for three age groups. Treatment provided was also calculated in 13 treatment categories. Trend analyses were performed to study changes during the study period.

Results: Restorative treatments $(968,772 ; 23.6 \%)$, examinations $(658,394 ; 16.1 \%)$, radiographs taken $(529,875 ; 12.9 \%)$ anaesthesia used $(521,169 ; 12.7 \%)$ and emergency treatments $(348,229 ; 8.5 \%)$ made up $73.8 \%$ of all treatment measures during the entire study period. Periodontal treatment (7.8\%) and caries prevention (3.9\%) made up a small part of the care provided and prosthetics and treatment of TMJ disorders were extremely uncommon (fewer than 1\%). Treatments related to caries (restorative treatment, examinations, endodontics, emergencies, anaesthesia and radiographs) made up $60.4 \%$ of the dental personnel's treatment time. During the study period, statistically significant increasing trends were found for radiographs $\left(p<0.001^{* * *}\right)$, anaesthesia $\left(p=0.003^{* *}\right)$ and total number of treatments $\left(p=0.009^{* *}\right)$. There was a slight decreasing trend in treatment need among the youngest adults (18-39years; $p=0.033^{*}$ ).

Conclusion: Compared with the results of national epidemiological studies, insufficient periodontal treatment is provided and prosthetic treatment is almost totally neglected in the PDS. Rather, adults' dental treatment concentrates on treatment of caries. The unmet needs may be due to tradition, inadequate treatment processes or a lack of resources or failed salary incentives.
\end{abstract}

Keywords: Registers, Oral health, Treatment needs, Public dental service, Treatment measures

\section{Background}

In Finland, adults' oral health has been monitored by three nationally representative clinical epidemiological studies in 1980, 2000 and 2011 [1-3]. These studies have shown that adults in general have poor oral health: they have lost many teeth and edentulousness is still common, especially among the elderly. Caries prevalence has decreased slightly [1-3]

\footnotetext{
* Correspondence: jari.linden@lohja.fi

${ }^{1}$ Public Dental Service Lohja, Lohja, Finland

Full list of author information is available at the end of the article
}

but the periodontal conditions have not improved during recent decades [1-4]. Home care habits are not good [3]. In the neighbouring countries, Sweden and Denmark progress has been much better [5, 6]. In Germany, adults have better oral health [7].

Since the early 1970s, the Public Dental Service (PDS) has catered for most children and adolescents younger than 18 years. It offered examinations, prevention and all necessary care free of charge [8]. Since the 1980s, adults were successively given access to the subsidized dental services in the PDS, starting with the 18-25-year-olds

C C The Author(s). 2020 Open Access This article is licensed under a Creative Commons Attribution 4.0 International License, which permits use, sharing, adaptation, distribution and reproduction in any medium or format, as long as you give appropriate credit to the original author(s) and the source, provide a link to the Creative Commons licence, and indicate if changes were made. The images or other third party material in this article are included in the article's Creative Commons licence, unless indicated otherwise in a credit line to the material. If material is not included in the article's Creative Commons licence and your intended use is not permitted by statutory regulation or exceeds the permitted use, you will need to obtain permission directly from the copyright holder. To view a copy of this licence, visit http://creativecommons.org/licenses/by/4.0/. The Creative Commons Public Domain Dedication waiver (http://creativecommons.org/publicdomain/zero/1.0/) applies to the data made available in this article, unless otherwise stated in a credit line to the data. 
youngest age groups. Older adults were assumed to visit private dentists or clinical dental technicians (denturists) and pay for their treatments out-of-pocket [9].

The Dental Care Reform in 2001-2002 abolished all age restrictions and persons older than 46 years (born before 1956) were allowed to book appointments in the PDS [9]. After the onset of the Reform from 2001 to 2007 , adults' use of oral health services increased, perceived need for oral health care decreased and socioeconomic inequity in use of care decreased. However, socioeconomic inequalities in reporting the need for emergency care increased [10]. In the PDS, a third (36.4\%) of all treatment measures were still provided for children and adolescents in 2009 and waiting lists for adults were long [11]. About half (48.5\%) of the working aged (18-64-year-olds) who visited a dentist in 2009 had used private services and the other half (51.5\%) public services. Of the elderly (65+ years), 56.9\% had visited private dentists and $43.1 \%$ public dentists [12].

There are few studies on dental treatment provided in general $[6,13,14]$ and especially in a longitudinal perspective. Overall, developing outcome measures for oral health care and using them for evaluation and steering purposes is still just beginning [15].

The aim of this study was to survey treatment needs and treatment measures provided for adults over 17 years old in the Public Dental Service and changes in them during a 13-year period from 2001 to 2013.

\section{Methods}

As described in our previous article [8] we asked five PDS units in southern Finland, where the same specific electronic patient registration system [16] was in use, were asked to participate in the study. Ethical approval was provided by the National Institute for Health and Welfare (THL 1697284289204448) and permission to use the local data was granted by the directors of health services in each PDS unit. The total number of adult inhabitants $(>17$ years) in the participating PDS units' catchment areas was in 2001, 240,584 and in 2013, 262,703 persons [17].

Data on all the adults ( $>17$ years) who had visited the five PDS units during 2001-2013 were collected retrospectively from each municipal database. For each year, the numbers of all patients who had visited a dentist and all treatment measures provided by any professional category (dentists, dental hygienists and dental nurses) were extracted from the databases [8]. Data on need for basic periodontal or caries treatment $(\mathrm{CPI}>2, \mathrm{D}+\mathrm{d}>0)[18]$ were also collected.

The patients were grouped into three age categories (18-39 years, 40-64 years and 65+ years). The items of treatment provided were classified into 13 main treatment areas: clinical examinations including complementary examinations (laboratory tests etc.), preventive care (instruction of oral hygiene, dietary advice, fluoride varnish etc.), periodontics (scaling etc.), restorative care (permanent and temporary fillings, crowns of filling material), endodontics, treatment of temporomandibular disorders (TMD), orthodontics, prosthetics (crowns, bridges, removable dentures etc.), anaesthesia (local anaesthesia, sedatives, nitrous oxide), emergency treatment, radiology, oral surgery and other treatment (removal of sutures, local medications, certificates etc) [8].

To control the possible effect of some treatment measures being short and others time consuming, all treatment measures collected were converted into treatment time (minutes, hours) using the average durations of the treatment measures as observed in a recent Finnish study [19].

The R 3.3 environment for statistical computing was used for descriptive and inferential analyses. Annual numbers of patients, the numbers of the examined, those in need of treatment and sum of treatment categories as well as their proportions of total are presented [8]. Numbers of treatment measures per 1000 patients combined by age group are also presented.

To discover underlying trends, we modeled volumes of patients in treatment categories, total treatment need, agreement of treatment needs and the volume of preventive treatment as functions of year. After logarithmic transformation of volumes, our linear models assume constant percentage change over time, with deviations from the mean normal on the log-scale and with explicitly autocorrelated residuals [20]. Fits to data were adequate except for very low-volume categories of TMJ disorders and prosthetics. Significances are reported at the level $p<0.05$ [8].

\section{Results}

From the first study year (2001) to the last (2013), the number of adults having visited the PDS increased by $81.5 \%$ from 37,377 to 67,834 . The number of patients in the youngest age group (18-39-year-olds) increased only by $6.5 \%$ from 25,463 to 27,113 . The age group $39-64$ years-old increased by $183.5 \%$ from 9760 to 27,666 and the oldest group (65+ years) increased five-fold from 2154 to 13,055 (Table 1). The total number of adults treated during the 13-year study period was 203,619 (Table 1). This means that about $77.5 \%$ of the adult population had visited the PDS on one or more occasions during 2001-2013.

During the study period, the proportion of those in need of basic caries and periodontal treatment $(\mathrm{CPI}>2$, $\mathrm{D}+\mathrm{d}>0$ ) decreased slightly. A statistically significant decreasing trend could be found in the youngest age group (18-39 years) from 75 to $68 \%\left(p=0.033^{*}\right)$. In the age group 40-64 years the decrease was smaller, from 74 to $70 \%$ and the trend was not significant $(p=0.497)$. In the oldest age group $(65+$ years $)$ the corresponding figures were from 61 to $55 \%(p=0.394$; Table 1 ; Table 3$)$. 


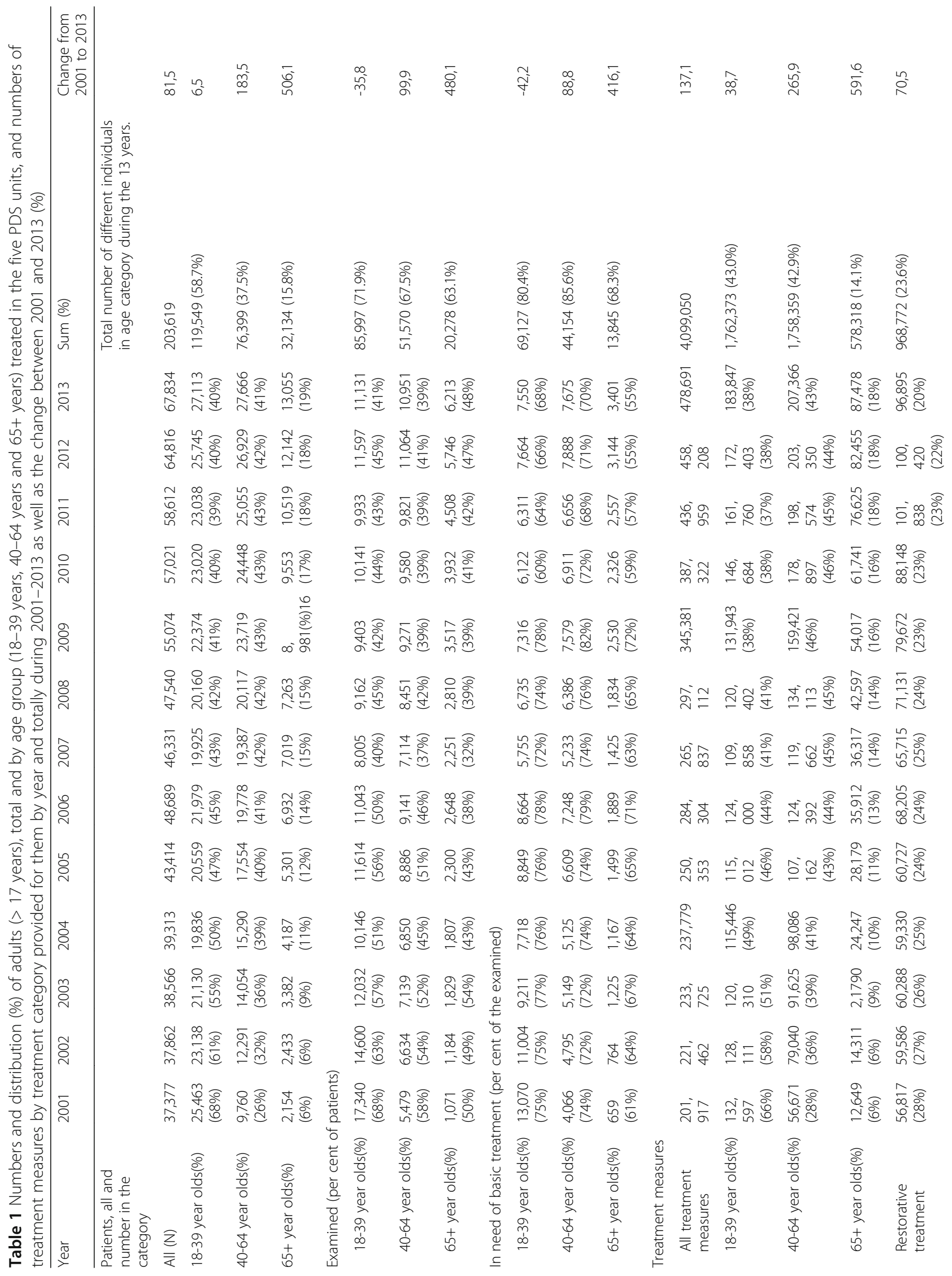




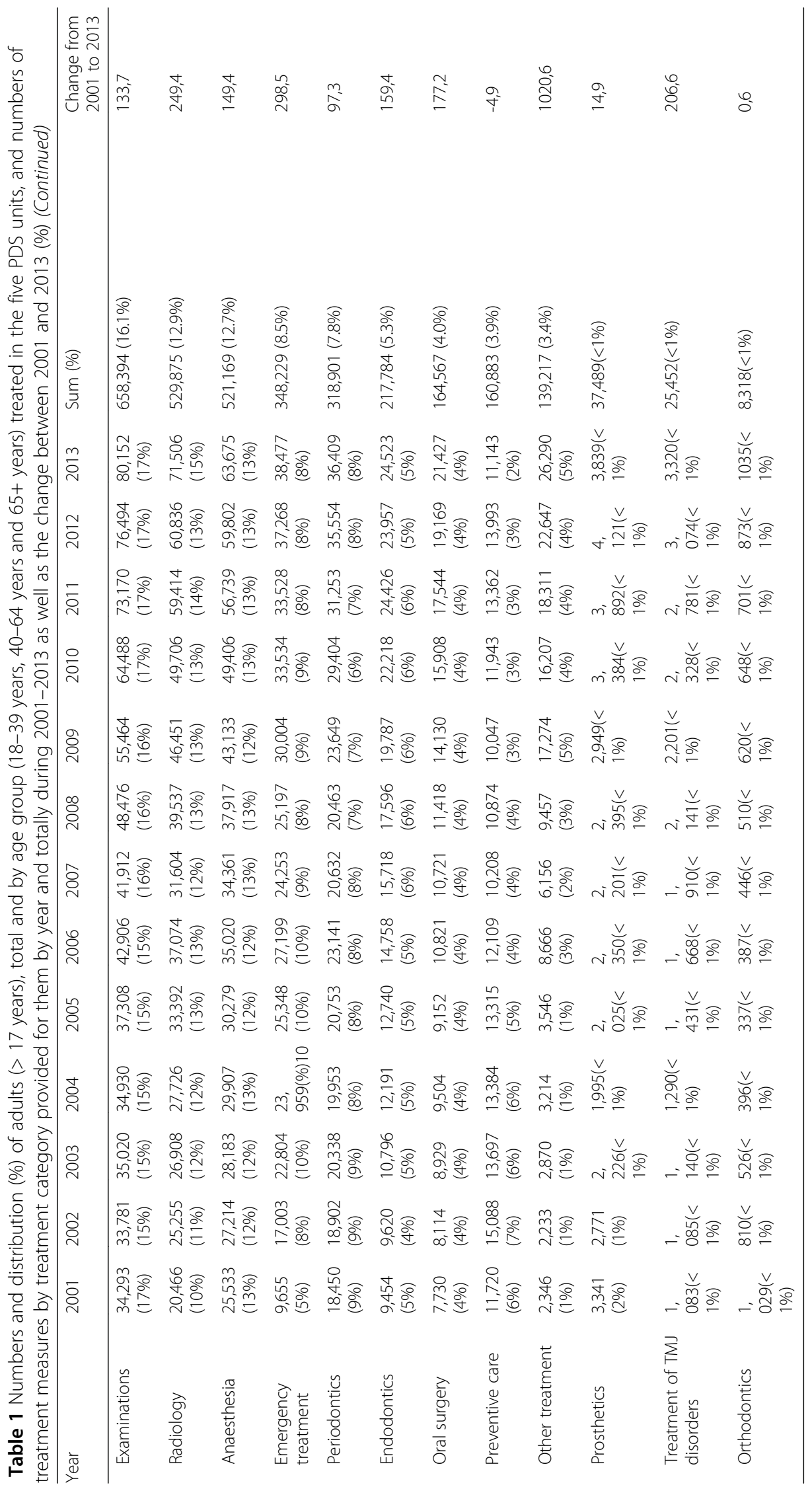


Altogether, 4,099,050 treatment measures were provided for the adults during the entire study period (Table 1). Almost equal shares were provided for the 18 -39-year-olds $(1,762,373,43.0 \%)$ and 40-64-year-olds $(1,758,359,42.9 \%)$. The $65+$ year-olds had had 578,318 (14.1\%) treatment measures. The 18-39- year-olds had on average had 14,742, the 40-64- year-olds 23,015 and the $65+$ year-olds 17,998 treatment measures per 1000 patients, respectively (Table 3 ).

Restorative treatment $(968,772 ; 23.6 \%)$, examinations $(658,394 ; 16.1 \%)$, radiology $(529,875 ; 12.9 \%)$ anaesthesia $(521,169 ; 12.7 \%)$ and emergency treatment $(348,229$; $8.5 \%$ ) made up $73.8 \%$ of all treatment measures during the entire study period. Periodontal treatment (7.8\%) and prevention $(3.9 \%)$ made up smaller parts of the care provided and prosthetics, treatment of TMD disorders and orthodontics were extremely infrequent (fewer than 1\%; Table 1).

As can be seen from Table 2, a major part of all preventive treatment $(43.5 \%)$ was provided for the youngest adults and most periodontal treatment $(45.5 \%)$, restorative treatment (45.8\%) and prosthetics $(52.0 \%)$ was for middle-aged adults. Other treatment categories were more evenly distributed among the age groups.

When treatment measures were converted into time [19], the share of periodontics doubled from 7.8 to $15.2 \%$ and endodontics from 5.3 to $11.6 \%$ respectively. The prosthetics share tripled from 0.9 to $2.7 \%$ but remained low. Radiology decreased from 12.9 to $3.2 \%$ and anaesthesia from 12.7 to $4.2 \%$. The share of restorative treatment increased from 23.6 to $28.4 \%$ and preventive treatment from 3.9 to $4.8 \%$. The share of examinations decreased slightly from 16.1 to $12.8 \%$ (Table 2). Treatments related to caries, restorative treatment $(28.4 \%)$, examinations $(12.8 \%)$, endodontics $(11.6 \%)$ and emergency treatment $(9.2 \%)$ made up $62.0 \%$ of dental personnel's treatment time (Table 3).

The total number of treatment measures provided increased from 5402 to 7057 per 1000 patients. Among the youngest age category (18-39 years), the mean number of treatment measures increased from 5207 to 6781 per 1000 patients, among the 40-64-year-olds from 5806 to 7495 per 1000 patients and among the oldest (65+ years) from 5872 to 6701 per 1000 patients (Fig. 1, Table 3).

Restorative treatment decreased from 1520 to 1428 treatment measures per 1000 patients, preventive care from 314 to 164 and prosthetics from 89 to 57 treatment measures.

Examinations increased from 917 to 1182 items per 1000 patients, radiology from 548 to 1054 items, anaesthesia from 683 to 939, periodontics from 494 to 537, emergency treatment from 258 to 567 and endodontics from 253 to 362 treatment measures respectively (Table 3 ).

Preventive treatment measures decreased among the 18-39-year-olds from 245 to 153 among the 40-64-yearolds; from 416 to 130 items and among the $65+$ year-olds the decrease was from 659 to 262 treatment measures per 1000 patients per year.

A statistically significant increasing trend was found in the total number of treatment measures provided from 2001 to 2013 for the youngest age group (18-39 years) $\left(p=0.003^{* *}\right)$ and for the 40-64-year-olds $\left(p=0.015^{*}\right)$. For the oldest group (65+ years), the trend was not statistically significant. The increasing trends in radiology $\left(p<0.001^{* * * *}\right)$, anaesthesia $\left(p=0.003^{* * *}\right)$ and oral surgery $\left(p=0.004^{* * *}\right)$ were statistically significant. The decreasing trend in preventive care was statistically significant $(p=$ $0.003^{* *}$; Table 4).

A statistically highly significant increasing trend was found in radiology for all age groups $\left(p<0.001^{* * * *}\right)$ through the years. When studying treatment profiles over patients' age categories, there was an increasing trend in examinations provided for the 40-64-years-olds $\left(p=0.010^{*}\right)$, in anaesthesia among the $18-39$-year-olds $\left(p<0.001^{* * *}\right)$ and the 40-64-year-olds $\left(p=0.002^{* * *}\right)$. A statistically significantly increasing trend was found in endodontic treatment among the 18-39-year-olds $(p<$ $\left.0.001^{* * * *}\right)$ and in oral surgery among the $18-39$-year-olds $\left(p=0.002^{* *}\right)$. The only treatment category having a statistically significantly decreasing trend was preventive care, among the 40-64-year-olds $\left(p=0.009^{* *}\right)$ and among the $65+$ year-olds $(p=0.002 * * ;$ Table 4$)$.

There were on average almost five times (483.5\%) more preventive treatment measures per patient among those not in need of treatment compared with those in need of treatment in every age group. In addition, among those in need of treatment there was a decreasing trend in preventive treatment measures per 1000 patients. Among the 40 64-year-olds from 2287 to $1383(p=0.569)$ and among the $65+$ year-olds from 3759 to 1297 treatment measures per patient ( $p=0.958$; Table 3$)$.

\section{Discussion}

In Finland, many kinds of statistical information on the performance of the public dental services have been collected by the individual PDS-units. Recording of certain oral health indices considering treatment needs and treatment measures is mandatory and part of each PDS dentist's salary is based on the treatment measures provided. Thus, data from the PDS records have been considered reliable [21]. There was little information about dental treatment provided in Finland before the national study in the year $2009[11,12]$. The treatment profiles in the PDS units participating in this study were in line with the previously mentioned national study [11] indicating that the chosen units, covering $5.9 \%$ of the population, were not outliers among the Finnish PDS-units. The results of this study can thus be generalised to middle sized or big towns in southern Finland. A limitation is that no information on social background of the 
Table 2 Distribution (\%) of treatment measures provided for adults in the five Finnish PDS units by patient age group (18-39 years, 40-64 years and 65+ years) for each of the main treatment domain during 2001-2013. Distribution (\%) of treatment measures converted to treatment time using the Helsinki study on time used for different treatment measures [19] by age group

\begin{tabular}{|c|c|c|c|c|c|c|c|c|}
\hline \multirow[b]{2}{*}{$\begin{array}{l}\text { Treatment } \\
\text { measures }\end{array}$} & \multicolumn{3}{|c|}{$\begin{array}{l}\text { Distribution of treatment } \\
\text { measures by age, } \%\end{array}$} & \multirow[b]{2}{*}{$\begin{array}{l}\text { Distribution of all } \\
\text { treatment measures, } \%\end{array}$} & \multicolumn{3}{|c|}{$\begin{array}{l}\text { Distribution of treatment } \\
\text { measures converted to } \\
\text { treatment time by age, } \%\end{array}$} & \multirow[b]{2}{*}{$\begin{array}{l}\text { Distribution of all treatment measures } \\
\text { converted to treatment time, } \%\end{array}$} \\
\hline & $\begin{array}{l}18-39 \\
\text { year } \\
\text { olds }\end{array}$ & $\begin{array}{l}40-64 \\
\text { year } \\
\text { olds }\end{array}$ & $\begin{array}{l}65+ \\
\text { year } \\
\text { olds }\end{array}$ & & $\begin{array}{l}18-39 \\
\text { year } \\
\text { olds }\end{array}$ & $\begin{array}{l}40-64 \\
\text { year } \\
\text { olds }\end{array}$ & $\begin{array}{l}65+ \\
\text { year } \\
\text { olds }\end{array}$ & \\
\hline $\begin{array}{l}\text { Restorative } \\
\text { treatment }\end{array}$ & 39.1 & 45.8 & 15.1 & 23.6 & 38.8 & 46.4 & 14.8 & 28.4 \\
\hline Examinations & 43.5 & 41.5 & 15.0 & 16.1 & 44.8 & 40.6 & 14.6 & 12.8 \\
\hline Radiology & 44.8 & 43.4 & 11.8 & 12.9 & 45.1 & 42.7 & 12.2 & 3.2 \\
\hline Anaesthesia & 52.4 & 38.3 & 9.3 & 12.7 & 52.6 & 38.2 & 9.2 & 4.2 \\
\hline $\begin{array}{l}\text { Emergency } \\
\text { treatment }\end{array}$ & 41.1 & 44.0 & 13.9 & 8.5 & 41.0 & 44.8 & 14.2 & 9.2 \\
\hline Periodontics & 39.0 & 45.5 & 15.5 & 7.8 & 36.2 & 47.6 & 16.2 & 15.2 \\
\hline Endodontics & 45.4 & 44.8 & 9.8 & 5.3 & 46.1 & 45.0 & 8.9 & 11.6 \\
\hline Oral surgery & 40.1 & 40.1 & 19.8 & 4.0 & 44.3 & 38.7 & 17.0 & 3.8 \\
\hline Preventive care & 43.5 & 36.4 & 20.1 & 3.9 & 44.3 & 35.8 & 19.9 & 4.8 \\
\hline Other treatment & 44.2 & 40.0 & 15.8 & 3.4 & 42.3 & 40.5 & 17.2 & 3.1 \\
\hline Prosthetics & 11.3 & 52.0 & 36.7 & 0.9 & 9.2 & 55.2 & 35.5 & 2.7 \\
\hline $\begin{array}{l}\text { Treatment of TMD } \\
\text { disorders }\end{array}$ & 43.9 & 46.2 & 9.9 & 0.6 & 46.9 & 45.3 & 7.8 & 0.9 \\
\hline Orthodontics & 91.0 & 8.6 & 0.4 & 0.2 & 91.2 & 8.4 & 0.3 & 0.2 \\
\hline All & 43.0 & 42.9 & 14.1 & 100 & 41.0 & 44.2 & 14.8 & 100 \\
\hline
\end{tabular}

patients is collected in the PDS register and that the information on treatment needs and oral health indicators was rather crude.

The results showed that from 2001 to 2013, the number of adults (18+ years) treated in the participating PDS-units increased by $81.5 \%$. In 2001, the shares of young ( $<18$ years) and adult patients were 51.5 and $48.5 \%$ respectively and in 2013 these were 36.8 and $63.2 \%$ [22]. This change was in line with the political intentions of the Dental Care Reform in 2001 aiming to improve adults' access to the PDS.

Overall, during the 13-year study period, most adults living in the local municipalities (77.5\%) had visited the PDS on some occasion. The legal obligation to organise emergency dental services for all inhabitants in its PDS uptake-area was included in the Dental Care Reform; this certainly explains a big part of the expanded use [23]. It was obvious from this study that most new patients were working age (18-64 years) adults. The share of older patients grew only from three to $12 \%$. In 2000 , $44 \%$ of the elderly were still edentulous in Finland [2]. During the study period, the number of dentists increased by $61.4 \%$ and the number of auxiliaries by $267.9 \%$ in the participating PDS units. The increased resources were used in treatment of adults only.
The study showed that the clinical treatment provided concentrated strongly on treating caries and its consequences. Examinations, restorative treatment, endodontics and emergencies made up $53.5 \%$ of all treatment measures and took $62.0 \%$ of the total treatment time of the staff during the whole study period. This can be regarded to be a disproportional share because the national epidemiological studies [1-3] have shown that, in addition to caries, gingivitis and periodontitis and great numbers of missing teeth even in anterior visible sectors without prosthetic devices are common in Finnish adults. Periodontal treatment made up only $7.8 \%$ of all treatment measures provided and $15.2 \%$ of the total treatment time. A worrying finding was that the share of preventive treatment was generally lower among those in need of treatment than those not in need of basic periodontal or restorative treatment.

The findings of the present study can be roughly compared with available data from the PDS in Sweden, where $46 \%$ of the 10 million treatment measures registered for the year 2017 in the PDS were examinations, $20 \%$ were periodontal, $16 \%$ restorative and $10 \%$ preventive treatment measures [24]. The corresponding values in this study in 2013 were $16.7,7.6,20.2$ and $2.3 \%$. It is evident that despite better oral health, Swedes received more examinations, periodontal and preventive treatment $[2,3,5]$. 
Table 3 Numbers of treatment measures per 1000 patients provided for adults (> 17 years) combined by age group (18-39 years, 40-64 years and 65+ years) in the five PDS units from 2001 to 2013

\begin{tabular}{|c|c|c|c|c|c|c|c|c|c|c|c|c|c|c|}
\hline & Year & 2001 & 2002 & 2003 & 2004 & 2005 & 2006 & 2007 & 2008 & 2009 & 2010 & 2011 & 2012 & 2013 \\
\hline $18-39 y$ & All & 5207 & 5537 & 5694 & 5820 & 5594 & 5642 & 5514 & 5972 & 5897 & 6372 & 7021 & 6697 & 6781 \\
\hline $18-39 y$ & RestorativeTreatment & 1459 & 1451 & 1388 & 1355 & 1257 & 1216 & 1219 & 1263 & 1172 & 1230 & 1399 & 1224 & 1147 \\
\hline $18-39 y$ & Examinations & 940 & 894 & 896 & 889 & 866 & 869 & 860 & 975 & 944 & 1076 & 1179 & 1103 & 1110 \\
\hline $18-39 y$ & Radiology & 563 & 684 & 707 & 722 & 784 & 786 & 688 & 825 & 833 & 841 & 997 & 931 & 1079 \\
\hline $18-39 y$ & Anaesthesia & 731 & 775 & 806 & 875 & 823 & 868 & 903 & 963 & 927 & 1023 & 1152 & 1095 & 1104 \\
\hline $18-39 y$ & EmergencyTreatment & 213 & 383 & 525 & 569 & 539 & 524 & 486 & 501 & 498 & 525 & 530 & 546 & 536 \\
\hline $18-39 y$ & PreventiveCare & 245 & 322 & 315 & 313 & 298 & 230 & 202 & 218 & 188 & 219 & 220 & 212 & 153 \\
\hline $18-39 y$ & Periodontology & 482 & 463 & 454 & 440 & 415 & 405 & 371 & 332 & 339 & 441 & 427 & 459 & 447 \\
\hline $18-39 y$ & EndodonticTreatment & 232 & 223 & 262 & 306 & 282 & 306 & 354 & 385 & 373 & 405 & 442 & 387 & 405 \\
\hline $18-39 y$ & TreatmentOfTemporomadibularDisorders & 28 & 28 & 29 & 33 & 32 & 35 & 40 & 43 & 41 & 42 & 44 & 46 & 50 \\
\hline $18-39 y$ & Orthodontics & 35 & 29 & 22 & 18 & 15 & 16 & 20 & 23 & 26 & 26 & 27 & 31 & 37 \\
\hline $18-39 y$ & Prosthetics & 40 & 34 & 18 & 10 & 9 & 10 & 6 & 8 & 8 & 10 & 11 & 7 & 10 \\
\hline $18-39 y$ & OtherTreatment & 63 & 64 & 82 & 89 & 91 & 182 & 153 & 211 & 319 & 290 & 318 & 371 & 406 \\
\hline $18-39 y$ & OralSurgery & 175 & 185 & 191 & 200 & 183 & 194 & 211 & 224 & 228 & 243 & 274 & 284 & 297 \\
\hline $40-64 y$ & All & 5806 & 6431 & 6519 & 6415 & 6105 & 6289 & 6172 & 6667 & 6721 & 7317 & 7926 & 7551 & 7495 \\
\hline $40-64 y$ & RestorativeTreatment & 1668 & 1803 & 1773 & 1701 & 1573 & 1633 & 1646 & 1729 & 1676 & 1808 & 1976 & 1805 & 1648 \\
\hline $40-64 y$ & Examinations & 871 & 892 & 909 & 888 & 865 & 929 & 970 & 1078 & 1064 & 1174 & 1299 & 1229 & 1227 \\
\hline $40-64 y$ & Radiology & 553 & 698 & 719 & 731 & 817 & 812 & 743 & 901 & 908 & 961 & 1102 & 1028 & 1140 \\
\hline $40-64 y$ & Anaesthesia & 597 & 656 & 668 & 683 & 631 & 665 & 692 & 747 & 754 & 850 & 947 & 919 & 941 \\
\hline $40-64 y$ & EmergencyTreatment & 358 & 559 & 678 & 675 & 648 & 625 & 586 & 573 & 604 & 657 & 620 & 623 & 618 \\
\hline $40-64 y$ & PreventiveCare & 416 & 487 & 391 & 363 & 292 & 214 & 169 & 183 & 139 & 177 & 205 & 177 & 130 \\
\hline $40-64 y$ & Periodontology & 531 & 577 & 623 & 592 & 552 & 561 & 521 & 515 & 499 & 577 & 598 & 610 & 597 \\
\hline $40-64 y$ & EndodonticTreatment & 315 & 324 & 323 & 345 & 331 & 339 & 371 & 397 & 392 & 431 & 448 & 418 & 389 \\
\hline $40-64 y$ & TreatmentOfTemporomadibularDisorders & 33 & 33 & 33 & 36 & 39 & 38 & 49 & 52 & 45 & 45 & 57 & 54 & 55 \\
\hline $40-64 y$ & Orthodontics & 13 & 11 & 5 & 2 & 1 & 1 & 2 & 2 & 1 & 2 & 2 & 2 & 1 \\
\hline $40-64 y$ & Prosthetics & 159 & 107 & 81 & 70 & 62 & 66 & 69 & 63 & 70 & 74 & 83 & 79 & 64 \\
\hline $40-64 y$ & OtherTreatment & 60 & 51 & 68 & 78 & 77 & 178 & 121 & 193 & 315 & 281 & 303 & 331 & 378 \\
\hline $40-64 y$ & OralSurgery & 233 & 234 & 248 & 250 & 216 & 230 & 233 & 234 & 252 & 282 & 286 & 278 & 308 \\
\hline $65+y$ & All & 5872 & 5882 & 6443 & 5791 & 5316 & 5181 & 5174 & 5865 & 6015 & 6463 & 7284 & 6791 & 6701 \\
\hline $65+y$ & RestorativeTreatment & 1575 & 1577 & 1784 & 1541 & 1371 & 1323 & 1355 & 1497 & 1526 & 1636 & 1910 & 1673 & 1547 \\
\hline $65+y$ & Examinations & 865 & 877 & 977 & 887 & 815 & 785 & 849 & 984 & 1014 & 1153 & 1281 & 1236 & 1233 \\
\hline $65+y$ & Radiology & 336 & 347 & 554 & 534 & 553 & 541 & 495 & 657 & 698 & 718 & 841 & 756 & 821 \\
\hline $65+y$ & Anaesthesia & 505 & 499 & 522 & 504 & 427 & 403 & 420 & 477 & 501 & 530 & 616 & 565 & 592 \\
\hline $65+y$ & EmergencyTreatment & 340 & 522 & 644 & 559 & 547 & 480 & 458 & 491 & 505 & 564 & 550 & 531 & 525 \\
\hline $65+y$ & PreventiveCare & 659 & 678 & 455 & 387 & 387 & 408 & 414 & 386 & 283 & 270 & 301 & 312 & 262 \\
\hline $65+y$ & Periodontology & 468 & 449 & 590 & 519 & 478 & 455 & 449 & 471 & 471 & 538 & 612 & 601 & 594 \\
\hline $65+y$ & EndodonticTreatment & 219 & 196 & 213 & 201 & 215 & 192 & 210 & 254 & 238 & 247 & 286 & 225 & 213 \\
\hline $65+y$ & TreatmentOfTemporomadibularDisorders & 17 & 11 & 19 & 18 & 18 & 21 & 25 & 31 & 22 & 27 & 32 & 36 & 34 \\
\hline $65+y$ & Orthodontics & 4 & 2 & 0 & 0 & 0 & 0 & 0 & 0 & 0 & 0 & 1 & 0 & 0 \\
\hline $65+y$ & Prosthetics & 355 & 275 & 210 & 172 & 143 & 120 & 105 & 133 & 122 & 141 & 147 & 150 & 138 \\
\hline $65+y$ & OtherTreatment & 67 & 53 & 58 & 63 & 62 & 165 & 110 & 182 & 297 & 278 & 322 & 345 & 369 \\
\hline $65+y$ & OralSurgery & 463 & 395 & 418 & 407 & 300 & 288 & 285 & 302 & 338 & 360 & 387 & 361 & 373 \\
\hline All & All & 5402 & 5849 & 6060 & 6048 & 5767 & 5839 & 5738 & 6250 & 6271 & 6793 & 7455 & 7069 & 7057 \\
\hline
\end{tabular}


Table 3 Numbers of treatment measures per 1000 patients provided for adults (> 17 years) combined by age group (18-39 years, 40-64 years and 65+ years) in the five PDS units from 2001 to 2013 (Continued)

\begin{tabular}{|c|c|c|c|c|c|c|c|c|c|c|c|c|c|c|}
\hline & Year & 2001 & 2002 & 2003 & 2004 & 2005 & 2006 & 2007 & 2008 & 2009 & 2010 & 2011 & 2012 & 2013 \\
\hline All & RestorativeTreatment & 1520 & 1574 & 1563 & 1509 & 1399 & 1401 & 1418 & 1496 & 1447 & 1546 & 1737 & 1549 & 1428 \\
\hline All & Examinations & 917 & 892 & 908 & 889 & 859 & 881 & 905 & 1020 & 1007 & 1131 & 1248 & 1180 & 1182 \\
\hline All & Radiology & 548 & 667 & 698 & 705 & 769 & 761 & 682 & 832 & 843 & 872 & 1014 & 939 & 1054 \\
\hline All & Anaesthesia & 683 & 719 & 731 & 761 & 697 & 719 & 742 & 798 & 783 & 866 & 968 & 923 & 939 \\
\hline All & EmergencyTreatment & 258 & 449 & 591 & 609 & 584 & 559 & 523 & 530 & 545 & 588 & 572 & 575 & 567 \\
\hline All & PreventiveCare & 314 & 398 & 355 & 340 & 307 & 249 & 220 & 229 & 182 & 209 & 228 & 216 & 164 \\
\hline All & Periodontology & 494 & 499 & 527 & 508 & 478 & 475 & 445 & 430 & 429 & 516 & 533 & 549 & 537 \\
\hline All & EndodonticTreatment & 253 & 254 & 280 & 310 & 293 & 303 & 339 & 370 & 359 & 390 & 417 & 370 & 362 \\
\hline All & TreatmentOfTemporomadibularDisorders & 29 & 29 & 30 & 33 & 33 & 34 & 41 & 45 & 40 & 41 & 47 & 47 & 49 \\
\hline All & Orthodontics & 28 & 21 & 14 & 10 & 8 & 8 & 10 & 11 & 11 & 11 & 12 & 13 & 15 \\
\hline All & Prosthetics & 89 & 73 & 58 & 51 & 47 & 48 & 48 & 50 & 54 & 59 & 66 & 64 & 57 \\
\hline All & OtherTreatment & 63 & 59 & 74 & 82 & 82 & 178 & 133 & 199 & 314 & 284 & 312 & 349 & 388 \\
\hline All & OralSurgery & 207 & 214 & 232 & 242 & 211 & 222 & 231 & 240 & 257 & 279 & 299 & 296 & 316 \\
\hline
\end{tabular}

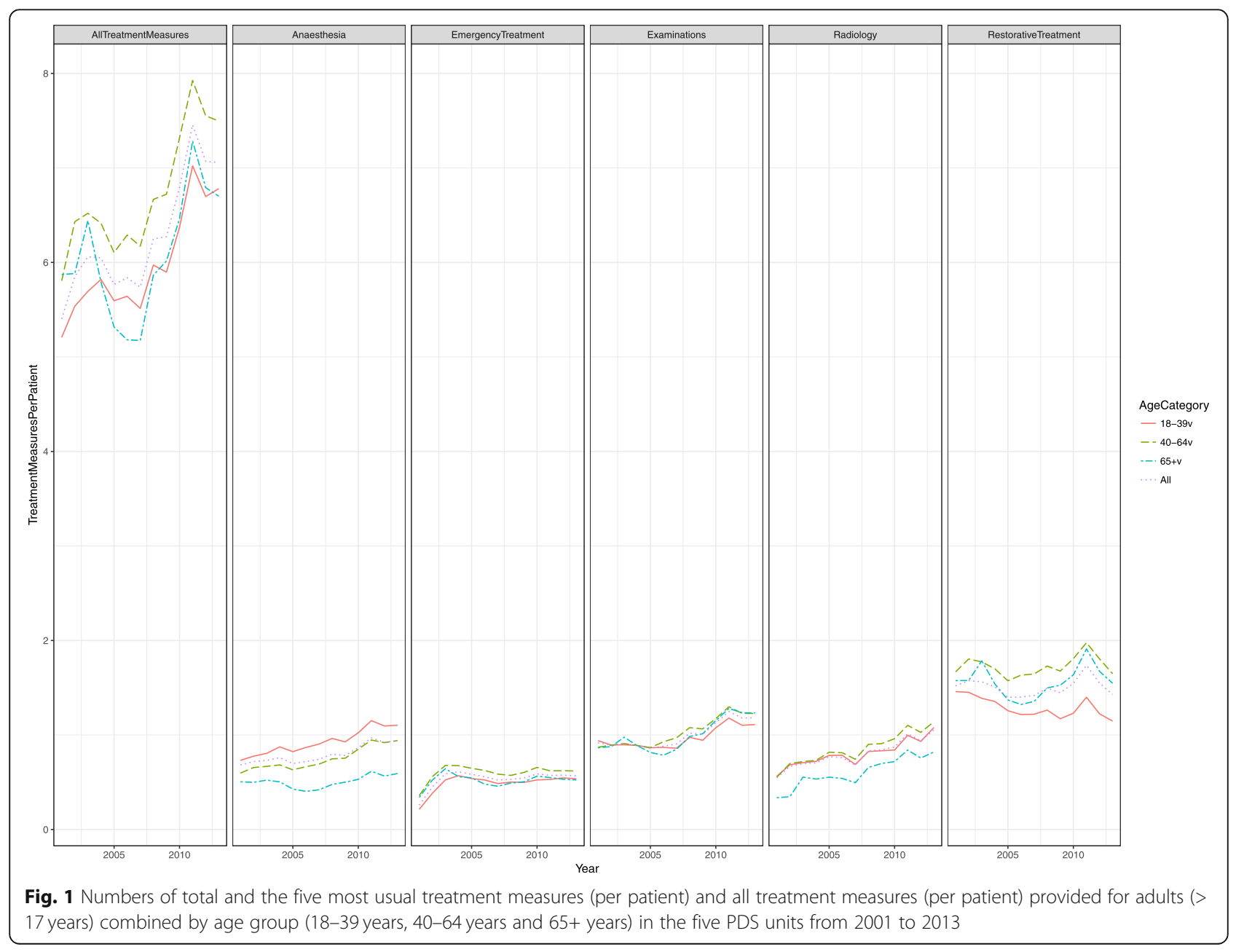


Table 4 Trend analysis on treatment need, on the number of treatment measures per patient in each treatment category provided for adult patients (> 17 years) and separately for the three age categories (18-39 years, 40-64 years and 65+ years) in the five PDS units. For the three separate age groups only statistically siategories are presented

\begin{tabular}{|c|c|c|c|c|c|}
\hline Treatment need & Age category & mu & $s d$ & $\mathrm{t}$ & $\mathrm{p}$ \\
\hline In need of treatment & $18-39 v$ & -0.014 & 0.006 & -2.442 & $0.033^{*}$ \\
\hline In need of treatment & $40-64 v$ & -0.004 & 0.005 & -0.702 & 0.497 \\
\hline In need of treatment & $65+v$ & -0.011 & 0.012 & -0.887 & 0.394 \\
\hline \multicolumn{6}{|l|}{ Prevention vs. Treatment need } \\
\hline No treatment need & All & 0.078 & 0.035 & 2.197 & 0.050 \\
\hline No treatment need & $18-39 v$ & 0.105 & 0.061 & 1.722 & 0.113 \\
\hline No treatment need & $40-64 v$ & -0.044 & 0.087 & -0.505 & 0.623 \\
\hline No treatment need & $65+v$ & 0.147 & 0.208 & 0.707 & 0.494 \\
\hline In need of treatment & All & -0.046 & 0.122 & -0.374 & 0.716 \\
\hline In need of treatment & $18-39 v$ & 0.013 & 0.124 & 0.105 & 0.919 \\
\hline In need of treatment & $40-64 v$ & -0.063 & 0.107 & -0.587 & 0.569 \\
\hline In need of treatment & $65+v$ & -0.004 & 0.083 & -0.053 & 0.958 \\
\hline \multicolumn{6}{|c|}{ All treatments and age categories } \\
\hline All treatments & All the adults & 0.022 & 0.007 & 3.114 & $0.009^{* *}$ \\
\hline All treatments & 18-39years & 0.021 & 0.006 & 3.746 & $0.003^{* *}$ \\
\hline All treatments & 40-64years & 0.021 & 0.007 & 2.864 & $0.015^{*}$ \\
\hline All treatments & $65+$ years & 0.011 & 0.018 & 0.618 & 0.549 \\
\hline \multicolumn{6}{|l|}{ Treatment categories and all ages } \\
\hline RestorativeTreatment & All the adults & -0.003 & 0.009 & -0.273 & 0.789 \\
\hline Examinations & All the adults & 0.021 & 0.017 & 1.218 & 0.249 \\
\hline Radiology & All the adults & 0.044 & 0.005 & 8.881 & $<0.001^{* * *}$ \\
\hline Anaesthesia & All the adults & 0.027 & 0.007 & 3.671 & $0.003^{* *}$ \\
\hline EmergencyTreatment & All the adults & 0.066 & 0.051 & 1.279 & 0.227 \\
\hline Periodontology & All the adults & 0.007 & 0.019 & 0.363 & 0.724 \\
\hline EndodonticTreatment & All the adults & 0.030 & 0.021 & 1.390 & 0.192 \\
\hline OralSurgery & All the adults & 0.035 & 0.010 & 3.571 & $0.004^{* *}$ \\
\hline PreventiveCare & All the adults & -0.059 & 0.016 & -3.711 & $0.003^{* *}$ \\
\hline OtherTreatment & All the adults & 0.176 & 0.014 & 12.374 & $<0.001^{* * *}$ \\
\hline Prosthetics & All the adults & -0.038 & 0.034 & -1.130 & 0.282 \\
\hline Treatment of TMJ disorders & All the adults & 0.048 & 0.006 & 8.046 & $<0.001^{* * *}$ \\
\hline Orthodontics & All the adults & -0.049 & 0.060 & -0.815 & 0.432 \\
\hline \multicolumn{6}{|c|}{ For the three age categories, only statistically significant treatment categories are presented. } \\
\hline Examinations & 40-64years & 0.030 & 0.010 & 3.083 & $0.010^{*}$ \\
\hline Radiology & 18-39years & 0.041 & 0.005 & 7.747 & $<0.001^{* * *}$ \\
\hline Radiology & 40-64years & 0.050 & 0.004 & 11.406 & $<0.001^{* * *}$ \\
\hline Radiology & $65+$ years & 0.070 & 0.012 & 5.561 & $<0.001^{* * *}$ \\
\hline Anaesthesia & 18-39years & 0.035 & 0.003 & 10.902 & $<0.001^{* * *}$ \\
\hline Anaesthesia & 40-64years & 0.038 & 0.009 & 4.174 & $0.002^{* *}$ \\
\hline EndodonticTreatment & 18-39years & 0.051 & 0.011 & 4.761 & $<0.001^{* * *}$ \\
\hline OralSurgery & 18-39years & 0.044 & 0.011 & 4.055 & $0.002^{* *}$ \\
\hline PreventiveCare & 40-64years & -0.099 & 0.031 & -3.155 & $0.009^{* *}$ \\
\hline PreventiveCare & $65+$ years & -0.074 & 0.019 & -3.953 & $0.002^{* *}$ \\
\hline
\end{tabular}


Table 4 Trend analysis on treatment need, on the number of treatment measures per patient in each treatment category provided for adult patients (> 17 years) and separately for the three age categories (18-39 years, 40-64 years and 65+ years) in the five PDS units. For the three separate age groups only statistically siategories are presented (Continued)

\begin{tabular}{llllll}
\hline Treatment need & Age category & $\mathrm{mu}$ & $\mathrm{sd}$ & $\mathrm{t}$ & $\mathrm{p}$ \\
\hline OtherTreatment & 18 -39years & 0.173 & 0.013 & 13.394 & 11.602 \\
OtherTreatment & 40-64years & 0.183 & 0.016 & $0.001^{* * *}$ \\
OtherTreatment & 65 +years & 0.183 & 0.024 & 7.768 & $<0.001^{* * *}$ \\
Treatment of TMJ disorders & 18-39years & 0.049 & 0.005 & 10.281 & $<0.001^{* * *}$ \\
Treatment of TMJ disorders & 40-64years & 0.048 & 0.007 & 6.685 & $<0.001^{* * *}$ \\
Treatment of TMJ disorders & 65 +years & 0.082 & 0.008 & 9.928 & $<0.001^{* * *}$ \\
\hline
\end{tabular}

Also, in the private sector in Finland, restorative therapy dominates adult dental care although some more periodontal treatment is provided [12]. In general, the private sector is seen to provide more frequent and more comprehensive care to a smaller group of adult patients, whereas in the PDS more effort goes to examinations and emergency care and a greater proportion of adults receive irregular care due to long waiting lists and no recall system $[12,25]$.

Public dentists in Finland feel that their competence is weak in periodontal treatment [26]. This may be because dentists may think that much of this treatment should be given by the dental hygienists, but probably also because the PDS until 2002 catered mainly for children, adolescents and young adults. Lack of experience and skills is also likely to explain the fact that very little prosthetic treatment $(0.2 \%)$ was provided by the participating PDS units. The cost of prosthetic treatment and especially fixed prosthetics has been high even in the PDS, because the technical work has to be bought from the private sector. The fact that some treatments are neglected also reflects lack of resources, especially specialists in adult dental care. Officially, prosthetics is included in the treatment palette of the PDS. Poor access to proper crown and bridge therapy and its high cost have resulted in restorative treatment practices where large composite fillings and crowns are used with wide indications, often leading to repetitive circle of restorative work and thus raising the share of restorative treatment [27]. Provision of questionable restorative treatment can also increase the need for endodontic treatment. In the national epidemiological study in $2000,27 \%$ of the examined adults had at least one and $13 \%$ three or more teeth with apical periodontitis [2].

The public dentists (but not dental hygienists) have been encouraged to increase productivity by giving them salary increments from most treatment measures they have provided except radiography and preventive care. The salary increment is about $30-40 \%$ of the total wages. The most profitable treatments are and have long been examinations and restorative treatment. Thus, the findings reflect great discrepancy between the objectives of the Dental Care
Reform in 2002 to give older adults born before the year 1956 access to the PDS and still continuing the use of old incentives aimed to steer productivity in treatment of young adults needing mostly treatment of caries when the incentives were created in 1980s.

Since this study period ended, a number of national best practice guidelines for most treatments in adult oral health care have been published to facilitate clinical treatment planning in Finland. These evidence-based recommendations include treatment of dental caries [28], temporomandibular disorders [29], restorative dentistry [30], dental infections [31] and prosthetics [32]. However, it is well-known that even the best guidelines will not become implemented automatically in daily practice but require education and leadership [33].

Overall, there has been little political pressure to look at the quality of adult dental care [34]. Chief medical officers, the superiors of the chief dental officers in the decentralised PDS organisation, are not sufficiently familiar with the challenges in adult dental care after the age restrictions were abolished in the PDS [35] and there has been no other interest group to drive this objective.

This study shows that use of routine administrative data collected from the databases of PDS organizations can improve transparency of oral health service delivery and give new tools for the managers and political leaders. The results also indicate that the PDS might be insufficiently resourced or the personnel is not efficiently used in providing care for adults. Besides the young, adults should also be included in a recall system in the PDS to guarantee improvement of their oral health. The present incentives connected with salary that favor selected treatment measures need to be replaced by a system that enables adequate comprehensive care and includes prevention.

\section{Conclusions}

Adults' dental treatment in the PDS concentrates on treatment of caries. Compared with the results of national epidemiological studies, periodontal treatment is insufficient and prosthetic treatment is almost totally neglected. The big increase in radiography suggests that the quality of examinations has improved. There was no 
significant decrease in treatment need except for the youngest adults. The unmet needs may be due to tradition, inadequate treatment processes, lack of resources or failed salary incentives.

\section{Abbreviations}

AR residual: Autoregressive residual; CPI: Community Periodontal Index; D: Number of permanent decayed teeth; DMFT: Number of decayed, missed and filled teeth; ns: Not significant; PDS: Public Dental Service; THL: The National Institute for Health and Welfare (Terveyden ja Hyvinvoinnin Laitos); TMD: Temporomandibular disorders

\section{Acknowledgements}

We are grateful to the PDS units that offered their data for our study. We would also like to thank Jari Moisanen, Miikka Ristkari and Esko Ristkari from In Net Ltd. (www.winhit.fi) for their valuable help in gathering the material for this study.

\section{Authors' contributions}

$J L$ and EW planned and designed the study. $J L$ organized the practicalities and the data collection. JL and JS analysed the data. EW helped to interpret the results. JL and EW drafted the manuscript. All authors read and approved the final paper.

\section{Funding}

No funding received.

\section{Availability of data and materials}

The data that support the findings of this study are available from the National Institute for Health and Welfare (THL) but restrictions apply to the availability of these data, which were used under licence for the current study, and are thus not publicly available. Data are, however, available from the authors upon reasonable request and with permission of the National Institute for Health and Welfare (THL) as well as the participating communities.

\section{Ethics approval and consent to participate}

Ethical Committee approval for this study was not necessary according to Finnish law and the obligations of the National Institute for Health and Welfare (THL). This study was considered to be routine work (quality assurance) at THL and the Department's Director approved the data collection. Also submitted as a separate file.

\section{Consent for publication}

Not applicable.

\section{Competing interests}

The authors declare that they have no competing interests.

\section{Author details}

${ }^{1}$ Public Dental Service Lohja, Lohja, Finland. ${ }^{2}$ Institute of Clinical Dentistry, Arctic University of Norway, Tromso, Norway. ${ }^{3}$ National Institute for Health and Welfare (THL), Helsinki, Finland. ${ }^{4}$ Finland Reaktor Itd, Helsink, Finland.

Received: 4 December 2019 Accepted: 26 March 2020

Published online: 21 April 2020

\section{References}

1. Vehkalahti M, Paunio I, Nyyssönen V, Aromaa A, ed. Suomalaisten aikuisten suunterveys ja siihen vaikuttavat tekijät (Abstract in English). Kansaneläkelaitoksen julkaisuja AL:34. Vammalan kirjapaino, Turku 1991. (Oral health of Finnish adults and determinant factors, English summary).

2. Suominen-Taipale L, Nordblad A, Vehkalahti M, Aromaa A. Eds. Oral health in the Finnish adult population. Health 2000 survey. Publications of the National Public Health Institute (KTL) B25. Hakapaino Oy: Helsinki; 2008.

3. Koskinen S, Lundqvist A, Ristiluoma N, eds. Terveys, toimintakyky ja hyvinvointi Suomessa 2011 In: THL Raportti 68. Tampere: Juvenes Print Suomen yliopistopaino Oy; 2012. (Health, functional capacity and welfare in Finland in 2011, English summary.).
4. Suomalaisen Lääkäriseura Duodecimin ja Suomen Hammasläkäriseura Apollonia ry:n asettama työryhmä. Parodontiitti. Käypähoito-suositus. http:// www.kaypahoito.fi/web/english/guidelineabstracts/guideline?id=ccs00082. Accessed 2018 Dec 30. (Finnish Best Practice Guideline for treatment of periodontal diseases, English summary.).

5. Wahlin $\AA$, Papias A, Jansson H, Norderyd O. Secular trends over 40 years in periodontal health and disease in individuals aged $20-80$ years in Jönköping, Sweden: repeated cross-sectional studies. J Clin Periodontol. 2018:45:1016-24. https://doi.org/10.1111/jcpe.12978.

6. Holt C. Brugen af og betaling for tandpleje i Danmark. Sverige og Norge Nor Tannlegeforen Tid. 2013;123:12-8 https://www.tandlaegebladet.dk/sites/ default/files/articles-pdf/20-29.pdf. Accessed 2019 Oct 3.

7. Jordan AR, Micheelis W. Fünfte Deutsche Mundgesundheitsstudie. Köln: Deutscher Zahnärzte Verlag DÄV; 2016.

8. Linden J, Widström E, Sinkkonen J. Children and adolescents' dental treatment in 2001-2013 in the Finnish public dental service. BMC Oral Health. 2019;19:131. https://doi.org/10.1186/s12903-019-0828-z.

9. Widström E, Agustdottir $H$, Byrkjeflot LI, Pälvärinne R, Christensen LB. Systems for provision of oral health care in the Nordic countries. Tandlaegebladet. 2015;119:702-11 https://www.tandlaegebladet.dk/sites/ default/files/articles-pdf/TB092015-702-711.pdf. Accessed 2019 Oct 3.

10. Raittio E. Use of oral health services and perceived oral health after the oral health care reform introduced during 2001-2002. The more comprehensive public coverage of Oral health care, the lower socioeconomic inequalities? Thesis. Kuopio: University of Eastern Finland; 2016.

11. Widström E, Linden J, Tiira H, Seppälä TT, Ekqvist M. Treatment provided in the public dental Service in Finland in 2009. Community Dent Health. 2015; 32:60-4.

12. Widström E, Linden J. Treatment provided in the public dental service and by private dentists in Finland. Oral Health Dent Manag. 2018;17:1024 https:/ www.omicsonline.org/open-access/treatment-provided-in-the-public-dentalservice-and-by-private-dentists-in-finland.pdf. Accessed 2019 Oct 3.

13. Guiney P, Felicia $H$, Whelton $N$, Woods $H$. Analysis of a payments database reveals trends in dental treatment provision. J Dent Res. 2013;92(7 Suppl): 63S-9S. https://doi.org/10.1177/0022034513484327.

14. Guiney H, Felicia P, Whelton H, Woods N. Comparing epidemiologically estimated treatment need with treatment provided in two dental schemes in Ireland. BMC Oral Health. 2012;12:31. https://doi.org/10.1186/1472-683112-31.

15. Hummel R, Bruers J, van der Galien O, van der Sanden W, van der Hejden G. Outcome measures for oral health based on clinical assessments and claims data: feasibility evaluation in practice. BMC Oral Health. 2017;17:125. https://doi.org/10.1186/s12903-017-0410-5.

16. WinHit, In Net OY; www.winhit.fi.

17. Statistics Finland. Population structure. http://www.stat.fi/til/vaerak/index. html. Accessed 2019 Oct 3.

18. Oral health surveys: basic methods - 5 th edition. World health organization. Geneve: WHO press; 2013.

19. Tarvonen P-L, Ekqvist M, Turunen S, Hiekkanen S, Suominen L. Helsingin terveyskeskuksen suun terveydenhuollon tuotteistushankkeen loppuraportti. Helsingin terveyskeskuksen raportteja 3. Helsinki 2012. (Time used for different dental treatment measures, in Finnish).

20. Chandler R, Scott M. Statistical methods for trend detection and analysis in the environmental sciences. New Jersey: Wiley; 2011. https://doi.org/10. 1002/9781119991571.

21. Hausen H, Kärkkäinen S, Seppä L. Caries data collected from public health records compared with data based on examinations by trained examiners. Caries Res. 2001;35:360-5. https://doi.org/10.1159/000047475.

22. Linden J, Josefsson K, Widström E. Frequency of visits and examinations in the public dental Service in Finland - a retrospective analysis, 2001-2013. BMC Oral Health. 2017;17:138. https://doi.org/10.1186/s12903-017-0436-8.

23. Niranen T, Widström $E$, Niskanen T. Oral health care reform in Finland aiming to reduce inequity in care provision. BMC Oral Health. 2008;28(8):39. https://doi.org/10.1186/1472-6831-8-3.

24. Årsrapport 2017. Svenskt kvalitetsregister för karies och parodontit. (Annual report 2017. The Swedish quality registry for caries and periodontal disease, in Swedish) http://www.skapareg.se/wp-content/uploads/2018/09/\%C3\%85 rsrapport-2017.pdf. Accessed 2019 Oct 3.

25. Widström E, Komu M, Mikkola H. Longitudinal register study of attendance frequencies in public and private dental services in Finland. Community Dent Health. 2013;30:143-8. 
26. Rantahakala L, Nihtilä A, Mäntylä P. Terveyskeskuksissa tarvetta parodontologiselle täydennyskoulutukselle, (Periodontal diagnosis and treatment practices in Helsinki's Metropolitan Public Dental Services). Suomen Hammasläkärilehti. 2012;1:24-32.

27. Nihtilä A, Widström E, Elonheimo O. Adult heavy and low users of dental services: treatment provided. Swed Dent J. 2016;40(1):21-32.

28. Suomalaisen Lääkäriseura Duodecimin ja Suomen Hammaslääkäriseura Apollonia ry:n asettama työryhmä. Karies (hallinta). Käypähoito-suositus, (Finnish Best Practice Guideline for management of caries, English summary). https://www.kaypahoito.fi/hoi50078. Accessed 2019 Oct 3.

29. Suomalaisen Lääkäriseura Duodecimin ja Suomen Hammaslääkäriseura Apollonia ry:n asettama työryhmä. Purentaelimistön toimintahäiriöt (TMD). Käypähoito-suositus, (Finnish Best Practice. Guideline for treatment of temporomandibular disorders, English summary). https://www.kaypahoito.fi/ hoi50057. Accessed 2019 Oct 3.

30. Suomalaisen Lääkäriseura Duodecimin ja Suomen Hammaslääkäriseura Apollonia ry:n asettama työryhmä. Hampaan paikkaushoito. Käypähoitosuositus, (Finnish Best Practice Guideline for tooth restoration, English summary). https://www.kaypahoito.fi/hoi50117. Accessed 2019 Oct 3.

31. Suomalaisen Läääriseura Duodecimin ja Suomen Hammaslääkäriseura Apollonia ry:n asettama työryhmä. Hammasperäiset äkilliset infektiot ja mikrobilääkkeet. Käypähoito-suositus, (Finnish Best Practice Guideline for use of antimicrobials in acute dentistry, English summary). https://www. kaypahoito.fi/hoi50090. Accessed 2019 Oct 3.

32. Suomalaisen Lääkäriseura Duodecimin ja Suomen Hammaslääkäriseura Apollonia ry:n asettama työryhmä. Lyhentyneen hammaskaaren hoito. Käypähoito-suositus, (Finnish Best Practice Guideline for treatment of shortened dental arch (SDA), English summary). https://www.kaypahoito.fi/ hoi50094. Accessed 2019 Oct 3.

33. Sipilä R, Lommi M-L. Hoitosuositukset eivät muutu hoitokäytännöiksi Itsestään. (treatment recommendations do not automatically translate into treatment practices, English summary). Duodecim. 2014;130:832-9.

34. Alestalo P. Management and leadership in the public dental Service in Finland between 2003 and 2011, thesis. Helsinki: University of Helsinki; 2015. https://helda.helsinki.fi/bitstream/handle/10138/153268/manageme. pdf? sequence=1\&isAllowed=y. Accessed 2019 Oct 3.

35. Ordell S, Söderfeldt B. Understanding politics? Some lessons from Swedish dentistry. Community Dent Health. 2009;26:239-43.

\section{Publisher's Note}

Springer Nature remains neutral with regard to jurisdictional claims in published maps and institutional affiliations.

Ready to submit your research? Choose BMC and benefit from:

- fast, convenient online submission

- thorough peer review by experienced researchers in your field

- rapid publication on acceptance

- support for research data, including large and complex data types

- gold Open Access which fosters wider collaboration and increased citations

- maximum visibility for your research: over $100 \mathrm{M}$ website views per year

At $\mathrm{BMC}$, research is always in progress.

Learn more biomedcentral.com/submissions 